\title{
ACUTE PSYCHOTIC DISORDERS INDUCED BY TOPIRAMATE
}

\section{Report of two cases}

\author{
Florindo Stella ${ }^{1}$, Dorgival Caetano ${ }^{2}$, Fernando Cendes ${ }^{3}$, Carlos A.M. Guerreiro ${ }^{3}$
}

\begin{abstract}
We report on two epileptic patients who developed acute psychosis after the use of topiramate (TPM). One patient exhibited severe psychomotor agitation, heteroaggressiveness, auditory and visual hallucinations as well as severe paranoid and mystic delusions. The other patient had psychomotor agitation, depersonalization, derealization, severe anxiety and deluded that he was losing his memory. Both patients had to be taken to the casualty room. After interruption of TPM in one patient and reduction of dose in the other, a full remission of the psychotic symptoms was obtained without the need of antipsychotic drugs. Clinicians should be aware of the possibility of development of acute psychotic symptoms in patients undergoing TPM treatment.
\end{abstract}

KEY WORDS: psychiatric disorders, hallucination, delusion, topiramate.

\begin{abstract}
Episódio psicótico agudo induzido por topiramato: relato de dois casos
RESUMO - Relatamos dois pacientes epilépticos que manifestaram quadro psicótico agudo induzido por topiramato (TPM). Um paciente apresentou agitação psicomotora grave, heteroagressividade, alucinações auditivas e visuais, e delírios de conteúdo paranóide e místico. O outro paciente apresentou agitação psicomotora, despersonalização, desrealização, ansiedade intensa e delírio de que estava perdendo a memória. Ambos os pacientes foram conduzidos ao serviço de emergência e, após a interrupção do TPM em um deles e redução da droga em outro, houve remissão total dos sintomas psicóticos sem necessidade de medicação antipsicótica. Alertamos os clínicos para o risco de surgimento de sintomas psicóticos em pacientes em uso do TPM.
\end{abstract}

PALAVRAS-CHAVE: transtornos psiquiátricos, alucinações, delírios, topiramato.

Topiramate (TPM) is an antiepileptic drug (AED) used as add-on therapy for generalized and partial seizures that are resistant to other antiepileptic drugs $^{1-6}$. It has also been proposed as a mood stabilizer for patients with bipolar disorders who have not responded to the traditional treatments ${ }^{7-9}$. Neuropsychiatric symptoms may emerge after the use of TPM, the most common complaints are: somnolence, dizziness, tiredness, ataxia, headache, depression, and cognitive impairment such as mental confusion, slow reasoning, speech difficulty, and disturbance of memory ${ }^{10-18}$. These symptoms ranged from moderate to severe, however, they progressively improved as treatment went on.

There are few reports in the literature regarding the association of TPM with psychotic disorders ${ }^{19,20}$.
The majority of the psychotic symptoms reported in scientific meetings lack in detail $\mathbf{s}^{11,21,22}$. Patients with history of prior psychotic or depressive symptoms had a tendency to develop the same type of mood disorder when put on TPM ${ }^{23}$.

The purpose of this paper is to report on two patients with epilepsy who presented psychotic outbursts after the use of TPM.

\section{CASES}

Patient A - A 42-year old male, engineer, married with two children. He had been treated for epileptic seizures since the age of two when he had his first episode of febrile seizures. Throughout his infancy he had several febrile seizures and later on developed partial complex seizures, in the absence of fever, with secondary generali-

\footnotetext{
IInstituto de Biociências, Universidade Estadual Paulista (UNESP), Rio Claro SP, Brasil; ${ }^{2}$ Departamento de Psicologia Médica e Psiquiatria, Faculdade de Ciências Médicas (FCM), Universidade Estadual de Campinas SP, Brasil (UNICAMP); ${ }^{3}$ Departamento de Neurologia, FCM, UNICAMP.
}

Received 29 May 2001, received in final form 5 October 2001. Accepted 18 October 2001.

Dr. Florindo Stella - Instituto de Biociências / Psicologia, UNESP - Caixa Postal 199 - 13506-900 Rio Claro SP - Brasil. 
zation, once a week. He had no family or personal history of psychiatric disorders. Between 1997 and 2000 he had ten electroencephalograms performed: five showed epileptiform activity in right fronto-temporal region; one showed epileptiform activity in left fronto-temporal region; two intermittent slow waves in right temporal region; one intermittent slow waves in left temporal region; and one was normal. Interictal brain SPECT (1997) suggested hypoperfusion in the right temporal region. Magnetic resonance imaging (MRI) displayed bilateral hippocampal atrophy with left-sided predominance and a small lesion in the corpus callosum.

He was treated with several AEDs in monotherapy and polytherapy, but was never seizure free. As he had been on carbamazepine CR $1600 \mathrm{mg} /$ day over a year without much improvement, he was put on TPM $50 \mathrm{mg} / \mathrm{day}$. This dose was gradually increased to $300 \mathrm{mg}$ daily. There were no significant side effects but a mild difficulty in recollecting recent facts. As the seizures did not improve, the TPM dosage was increased from $300 \mathrm{mg}$ to $350 \mathrm{mg} /$ day. Only one day after being on $350 \mathrm{mg} / \mathrm{day}$, he presented a fullblown psychotic episode: he woke up about 3 a.m. with severe psychomotor agitation, verbal and physical heteroaggressiveness, disorientation in time and space as well as regarding himself, saying that a serious bus accident with a great number of fatal victims was bound to happen and that he had received a mission from God to save people. He also had visual and auditory hallucinations: vision of Our Lady telling him that his epileptic seizures had been cured; and severe paranoid ideas of being haunted by the police and other persecutory auditory hallucinations. He was taken to a psychiatric outpatient facility where he became more agitated, broke objects and damaged the cars parked in the vicinity. He had to be stopped by the police and taken to a psychiatric hospital, where he was put on diazepam. Carbamazepine was maintained and TPM was withdrawn. He was then transferred to the Psychiatric Unit of the General Hospital of the State University of Campinas, where he stayed for 11 days. Total remission of the psychotic symptoms took place within 48 hours after TPM was completely taken off. This episode was unrelated to epileptic seizures. He was kept on diazepam for several days because of his high anxiety and carbamazepine CR $1600 \mathrm{mg} /$ day was maintained. There was no need for antipsychotic medication and stopping TPM did not affect the frequency or the clinical features of the epileptic seizures.

Patient B - A 41-year old female, divorced with two children, who worked as a nanny. She was being treated for temporal lobe epilepsy. She has had complex partial seizures with secondary generalization since the age of 12. From 1997 to 2000 five electroencephalograms were carried out: one displayed bilateral epileptiform activity in frontal regions; two showed epileptiform activity in right temporal region; and two were normal. The CAT scan reveled mild cerebellar atrophy and MRI showed mild diffuse cerebellar atrophy, without abnormalities in brain structures.

She underwent monotherapy as well as polytherapy with several AEDs which failed to bring the seizures under control. Over a period of 2 years she was treated with valproic acid twice daily in a total of $1000 \mathrm{mg} /$ day. Then TPM 50mg/day was introduced and gradually increased to $100 \mathrm{mg} /$ day taken twice. As the seizures were not controlled, the dosage of TPM was increased to $150 \mathrm{mg}$ per day and on this very same day, the patient reported a "strong strange feeling" in relation to her environment, depersonalization, derealization, severe anxiety, fear, restlessness, and psychomotor agitation. She shouted phrases like "I'm going mad", "I'm losing my memory" and "nobody believes in me". She was taken to the casualty room and medicated with diazepam. TPM was reduced from $150 \mathrm{mg}$ to $50 \mathrm{mg} /$ day which alleviate psychomotor agitation and the other symptoms. There was no need for antipsychotic medication. Again this psychotic episode was unrelated to the patient's epileptic seizures and she had no previous history of psychiatric disorders.

\section{DISCUSSION}

Although topiramate has been reported to be associated with various adverse effects like dizziness, giddiness, tiredness, psychomotor slowness, difficulty in attention and concentration, memory impairment, loss of weight and nephrolithiasis, it is considered a safe drug with good tolerance and favorable pharmacokinetics ${ }^{24,25}$. Despite the fact that its plasmatic level is lowered by drugs that induce hepatic metabolism ${ }^{4}$, it has relatively few adverse reactions and very little interaction with other medications ${ }^{26}$. When administered with carbamazepine, a potent enzymatic Cytochrome P450 inducer ${ }^{27,28}$, TPM undergoes $40 \%$ reduction of its plasmatic levels and clearance ${ }^{28}$. On the other hand, plasma levels of carbamazepine or its epoxide metabolite does not change significantly when TPM is added ${ }^{29}$. The simultaneous use of TPM and valproate increases the plasma levels of the first by $15 \%$. This has to be taken into account if valproate is eventually withdrawn. TPM, on the other hand, increases valproate clearance, thus reducing its plasma levels ${ }^{29}$.

Although Aldenkamp et al. ${ }^{17}$ claim that the risk of TPM impairing cognitive functions is relatively small in comparison with val proate, they report that patients on TPM did worse on short-term verbal memory test. In the same vein, TPM was shown to impair cognitive functioning, especially as regards memory ${ }^{18}$. TPM may interfere with mnemonic process, however, it is hard to judge the extent of it. According to ICD-10 criteria ${ }^{30}$ the two reported cases were diagnosed as acute psychotic disorder. The clinical 
features appeared suddenly and within a few days after increasing the TPM dosage. However, they quickly remitted after TPM was taken off or reduced.

The frequency of psychotic episodes related to TPM is low and the most common symptoms were delusions, visual and auditory hallucinations. Data on the adverse effects of TPM report only few cases of psychotic symptoms such visual and auditory hallucinations and paranoid delusions ${ }^{15,18}$, and these patients eventually warranted hospitalization ${ }^{18}$.

The risk of psychotic symptoms due to the interaction of therapeutic doses of TPM and carbamazepine needs further investigation. However, this interaction upon reducing the serum level of TPM, is likely "to protect" the patient from the risk of TPM intoxication provided that both drugs are in the therapeutic range. Therefore, the concomitant use of TPM and carbamazepine cannot be taken as responsible for the psychotic symptoms presented by the patients. These acute psychotic episodes seem to be have been entirely due to the use of TPM. Another finding that lends support to this hypothesis is the completeremission of the psychotic symptoms upon the withdrawal of TPM, although carbamazepine was maintained. Moreover, these patients did not need any antipsychotic medication. Only diazepam was added to reduce the patients' anxiety. .

\section{REFERENCES}

1. Brown SD, Wolf HH, Swinyard EA, Twyman RE, White HS. The novel anticonvulsant topiramate enhances GABA-mediated chloride flux (Abstract). Epilepsia 1993;34(Suppl 2):122.

2. Ben-Menachem E, Henriksen O, Dam M, et al. Double-blind, placebocontrolled trial of topiramate as add-on therapy in patients with refractory partial seizures. Epilepsia 1996;37:539-543.

3. Faught E, Wilder BJ, Ramsay RE, et al. The topiramate YD Study Group. Neurology 1996;46:1684-1690.

4. Privitera MD. Topiramate: a new antiepileptic drug. Ann Pharmacother 1997;31:1164-1173.

5. Biton V. Preliminary open-label experience with topiramate in primary generalized seizures. Epilepsia 1997;38(Suppl 1):42-44

6. Reife RA, Pledger G, Wu SC. Topiramate as adjunctive therapy in refractory partial epilepsy: pooled analysis data from five double-blind, placebo-controlled trials. Epilepsia 1997; 38(Suppl 1):31-33.

7. Marcotte D. Use of topiramate, a new anti-epileptic, as a mood stabilizer. J Affect Disord 1998;50:245-251.
8. McElroy SL, Suppes T, Keck PE, et al. Open-label adjunctive topiramate in the treatment of bipolar disorders. Biol Psychiatry 2000;47:1025-1033.

9. Calabrese JR. Update on the use of topiramate in bipolar disorder (Abstract). Am Psychiat Assoc 2000;44A:13-18.

10. Shorvon SD. Safety of topiramate: adverse events and relationships to dosing. Epilepsia 1996; 37(Suppl 2):18-22

11. Betts T, Smith K, Khan G. Severe psychiatric reactions to topiramate. Epilepsia 1997;38 (Suppl 3):64.

12. Rosenfeld WE, Sachdeo RC, Faught RE, Privitera M. Long-term experience with topiramate as adjunctive therapy and as monotherapy in patients with partial onset seizures: retrospective survey of open-label treatment. Epilepsy 1997;38(Suppl 1):34-36.

13. Sander JWAS. Practical aspects of the use of topiramate in patients with epilepsy. Epilepsia 1997;38(Suppl 1):56-58.

14. Matsuura M, Suzuki T, Sakai T, Kojima T. Anticonvulsivant-related psychoses in epilepsy. Epilepsia 1998;39(Suppl 5):59-60.

15. Kellet MW, Smith DF, Stockton PA, Chadwick DW. Topiramate in clinical practice: first year's postlicensing experience in a specialist epilepsy clinic. J Neurol Neurosurg Psychiatry 1999;66:759-763.

16. Martin R, Kuzniecky R, Ho S et al. Cognitive effects of topiramate, gabapentin, and lamotrigine in healthy young adults. Neurology 1999;52:321-327.

17. Aldenkamp AP, Baker G, Mulder OG, et al. A multicenter, randomized clinical study to evaluate the effect on cognitive function of topiramate compared with valproate as add-on therapy to carbamazepine in patients with partial-onset seizures. Epilepsia 2000;41:1167-1178.

18. Reife R, Pledger G, Wu SC. Topiramate as add-on therapy: pooled analysis of randomized controlled trials in adults. Epilepsia 2000;41 (Suppl.1):66-71.

19. Crawford P. An audit of topiramate use in a general neurology clinic Seiz Eur J Epilep 1998;7:207-211.

20. Khan A, Faught E, Gillian F, Kuzniecky R. Acute psychotic symptoms induced by topiramate. Seizure 1999;84:235-237.

21. Abou-Khalil B, Fakhoury T. Neuropsychiatric profile of high-dose topiramate. Epilepsia 1997;38(Suppl 8):207.

22. Khan A, Faught E, Kuzniecky R, Gilliam F, Laich E. Acute psychotic symptoms induced by topiramate. Epilepsia 1997;38(Suppl 8):97.

23. Trimble MR, Rusch N, Betts T, Crawford PM. Psychiatric symptoms after therapy with new antiepileptic drugs: psychopathological and seizure related variables. Seizure 2000;9:249-254.

24. Bialer M. Comparative pharmacokinetics of the newer antiepileptic drugs. Clin Pharmacokinet 1993;24:441-452.

25. Sadzot B. Pharma clinics. Medication of the month: topiramate (topamax). Rev Med Liege 2000;55:114-116.

26. Herranz JL. Current data on topiramate. Rev Neurol 2000;30 (Suppl.1) 32-36.

27. Spina E, Pisani F, Perucca E. Clinically significant pharmacokinetic drug interactions with carbamazepine: an update. Clin Pharmacokinet 1996; 31:198-214

28. Bourgeois BF. Drug interaction profile of topiramate. Epilepsia 1996;37(Suppl 2):14-17.

29. Bazire S. Psychotropic Drug Directory 2000. The professionals' pocke handbook and aide memoire. London: Quay Books Division 2000;257 275.

30. World Health Organization. The ICD-10 classification of mental and behavioural disorders: clinical descriptions and diagnostic guidelines. Geneva: WHO, 1992 